\title{
The use of an urticaria control test for the evaluation of omalizumab treatment response in patients diagnosed with chronic urticaria
}

\author{
Kronik ürtiker hastalarında omalizumab tedavi yanıtının değerlendirilmesinde ürtiker \\ kontrol testi kullanımı
}

\section{Burhan Engin, ๑ Sera Nur Yücesoy, ๑ Özge Așkın, ๑ Zekayi Kutlubay, ๑ Server Serdaroğlu} İstanbul University-Cerrahpașa, Cerrahpașa Faculty of Medicine, Department of Dermatology, İstanbul, Turkey

\begin{abstract}
Background and Design: Urticaria is a very common skin disease which is characterized by itchy, erythematous and edematous plaques. Angioedema can also be seen in half of the cases in addition to skin findings. In most cases of chronic urticaria, the underlying factor is not known. Omalizumab, a recombinant human monoclonal immunoglobulin $\mathrm{G}(\mathrm{IgG})$ antibody against $\lg \mathrm{E}$, is a safe treatment option in chronic urticaria cases which are resistant to treatment with antihistamines. This study aimed to evaluate the treatment responses of chronic urticaria patients taking omalizumab treatment with an urticaria control test (UCT).

Materials and Methods: One hundred fifty-four patients diagnosed with chronic urticaria taking omalizumab treatment attended our evaluation between January 1, 2017 and December 31, 2018. These patients were evaluated with an UCT every four weeks. Sixty-six patients who were evaluated with an UCT during the course of the following 12 weeks were statistically analyzed. Thirty-nine of the patients received a treatment shorter than 12 months (the first group), and the remaining 27 patients received treatment for longer than 12 months (the second group). The patients were analyzed according to the duration of their treatment.

Results: The first, second, and third average UCT scores of the 3 sequential applications for the first group were 9.16; 11.57; and 12.73; respectively. There was a statistically significant difference in the UCT scores between the 3 successive applications in the first group ( $p<0.05$ ). On the other hand, the first, second, and third average UCT scores of the 3 sequential applications for the the second group were 11.20; 11.40; and 12.36 respectively. There was statistically significant difference in the UCT scores between the 3 successive applications for the second group.

Conclusion: The effectiveness of omalizumab treatment in chronic urticaria patients with an UCT was investigated in this study. Omalizumab proved to be an effective treatment option in chronic urticaria patients.

Keywords: Chronic urticaria, omalizumab, urticaria control test

Öz

Amaç: Ürtiker toplumda oldukça sık görülen kaşıntılı eritemli ve ödemli plaklarla karakterize bir deri hastalı̆ıdır. Deri bulgularının yanında olguların yarısına anjiyoödem de eşlik edebilmektedir. Etiyolojisine bakıldığında çeşitli tetikleyici faktörlerin rol alabileceği düşünülse de özellikle kronik olgularda altta yatan sebep belirsizdir. Omalizumab immünoglobülin E'ye (IgE) karşı geliştirilmiş rekombinan insan monoklonal IgG antikoru olup yüksek doz antihistaminik tedavisine dirençli kronik spontan ürtiker olgularında güvenilir bir tedavi seçeneğidir. Bu çalışmada kronik spontan ürtiker tanılı antihistaminik tedavisine dirençli omalizumab tedavisi almakta olan hastaların tedavi yanıtlarının ürtiker kontrol testi (ÜKT) ile değerlendirilmesi amaçlanmaktadır.
\end{abstract}

Address for Correspondence/Yazışma Adresi: Burhan Engin MD, İstanbul University-Cerrahpaşa, Cerrahpaşa Faculty of Medicine, Department of Dermatology, İstanbul, Turkey Phone: +90 02124143000 E-mail: bengin@istanbul.edu.tr Received/Geliş Tarihi: 08.09.2019 Accepted/Kabul Tarihi: 22.05.2020 ORCID: orcid.org/0000-0002-5140-1926

(c) Copyright 2020 by Turkish Society of Dermatology and Venereology

Turkderm - Turkish Archives of Dermatology and Venereology published by Galenos Yayınevi. 


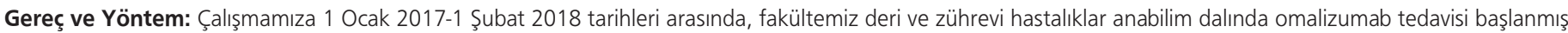

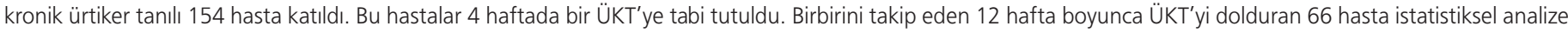

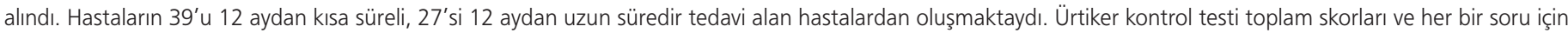
takip eden 3 uygulama arasında anlamlı bir fark olup olmadığı, varsa hangi uygulamalar arasında olduğu araştırıldı.

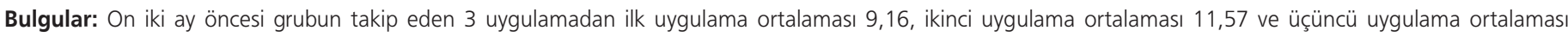

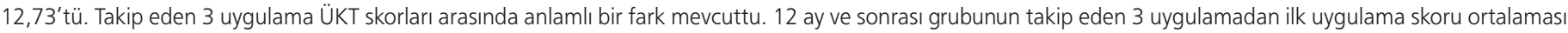

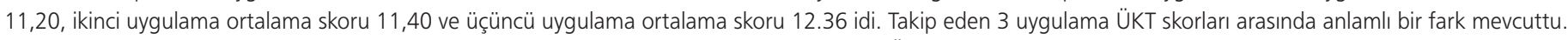

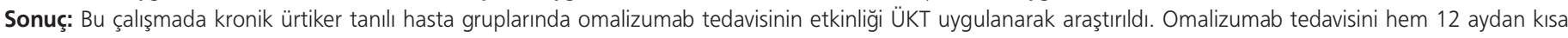
süreli, hem de 12 aydan uzun süreli alanlarda ÜKT sonuçlarında anlamlı bir iyileşme saptandı.

Anahtar Kelimeler: Kronik ürtiker, omalizumab, ürtiker kontrol testi

\section{Introduction}

Urticaria is a very frequently seen chronic skin disease that is characterized by pruritic erythematous plaques. Angioedema can also accompany half of the cases besides the skin findings. Although various triggering factors might have played a role considering its etiology, the underlying cause in the chronic cases in particular is undefined. Urticarial lesions are typically in the form of transient lesions, and the skin findings usually dissappear inherently within 24 hours without any remaining cutaneous finding. Notably mast cells and basophils play a role in the pathophysiology of urticaria. After activation of miscellaneous mediators, primarily histamine in particular, released from the mast cells and basophils plays a major role in the formation of pruritus and edema. The first step in the medical treatment of urticaria involves the use of the second generation antihistamines. However, if ineffective, it is suggested that the dosage be increased up to fourfold ${ }^{1}$. Leukotriene receptor antagonists can be added to the treatment of chronic urticaria where full control of the disease cannot be obtained by antihistamines. Omalizumab, a recombinant human monoclonal immunoglobulin $G$ (IgG) antibody developed against IgE is a safe treatment option in the chronic urticaria cases which are resistant to high-dosage antihistamine treatments. It binds the free IgE and prevents mast cell and basophil activation; thereby, decreasing the release of mediators responsible for the formation of pruritus and edema. Omalizumab is administered in a $300 \mathrm{mg}$ dosage as monthly subcutaneous injection, and following a six-month treatment, the response of the patient is evaluated. If the disease recurs, the treatment can be continued ${ }^{2}$.

This study aims to evaluate the omalizumab treatment responses of patients diagnosed with chronic urticaria resistant to antihistamines with the urticaria control test (UCT).

\section{Materials and Methods}

Our study carried out at our department of dermatology between January 1, 2017 and December 31, 2018 involved 154 patients who had been diagnosed with chronic urticaria. These patients were receiving the omalizumab treatment and underwent the UCT every four weeks. The UCT is a questionnaire composed of 4-questions. The patients were asked about their physical symptoms of urticaria, their quality of life, the need for antihistamines and the subjective control level of the disease. Each question includes 5 answer options with a score of 0 to 4 points, with 0 point denoting "very much" and 4 point denoting "not at all" (Figure 1). Sixty six Patients receiving the UCT during the course of the following 12 week were statistically evaluated. Thirty nine of the patients received a treatment lasting shorter than 12 months, and the remaining 27 longer than 12 . The total scores of the UCT were all evaluated as to whether or not there was an appreciable difference between the successive 3 applications for each question and in which application the difference was found, if any.

\section{Statistical Analysis}

The findings were analized by SPSS 20. For the duo and trio comparisons of the variants the Wilcoxon and Friedman tests were used, respectively. For the Friedman test $p<0.05$, for the Wilcoxon $p<0.016$ were accepted to have statistical significance.

\section{Results}

One hundred and fifty-four patients diagnosed with chronic urticaria were enrolled in the study, and 66 patients who underwent the UCT in the 3 successive treatment periods were statistically evaluated. Of the 66 patients, 39 patients received monthly omalizumab treatments for periods of less than 12 months and the remaining 27 for periods of 12 months or longer. The patients were assessed in two groups.

The first, second, and third average UCT scores of the 3 successive treatment period for the patient group receiving the omalizumab treatment for periods shorter than 12 months were 9.16; 11.57; and 12.73, respectively. There existed visible differences in the UCT scores between the 3 successive applications $(p<0.05)$ (Table 1). When compared with each other, there were statistically significant differences between the first and second, and between the first and third applications $(p<0.016)$ whereas the difference between the second and third applications was not statistically significant ( $p>0.016)$ (Table 2).

On the other hand, the patient group receiving the omalizumab treatment for periods longer than 12 months yielded the first, second, and third average UCT scores of 11.20; 11.40; and 12.36, respectively. Again there were appreciable differences in the UCT scores between the 3 successive treatment periods $(p<0.05)$ (Table 1). However, there were no significant differences between the applications themselves ( $p>0.016)$ (Table 2).

The UCT questions were analyzed one by one and the first question of the test was "how severe were your physical symptoms of urticaria in the last 4 weeks?". Of the scores given for the first group, the first application average was 2.16; the second 2.64; and the third 3.08; and there existed a significant difference between the 3 successive application scores $(p<0.05)$ (Table 3$)$. For the second group, the first, second, and third application averages were 2.16; 2,44; and 2.84, respectively, and there existed a significant difference between the 3 
1. How much have you suffered from the physical symptoms of the urticaria (itch, hives (welts) and/or swelling) in the last four weeks?
O very much
O much
O somewhat
O a little
O not at all

2. How much was your quality of life affected by the urticaria in the last 4 weeks?
O very much
O much
O somewhat
O a little
O not at all

3. How often was the treatment for your urticaria in the last 4 weeks not enough to control your urticaria symptoms?
$O$ very often
O often
O sometimes
O seldom
O not at all

4. Overall, how well have you had your urticaria under control in the last 4 weeks?

$O$ not at all $O$ a little $O$ somewhat $O$ well $O$ very well

Figure 1. Urticaria control test

\section{Table 1. Comparison of 3 consecutive urticaria control test scores of patients receiving omalizumab treatment}

\begin{tabular}{|c|c|c|c|}
\hline \multicolumn{2}{|l|}{ UCT scores } & Mean & $p$ \\
\hline \multirow{3}{*}{$\begin{array}{l}\text { The group receiving } \\
\text { treatments of }<12 \text {-month } \\
(n=37)\end{array}$} & $1^{\text {st }}$ application & 9.16 & \multirow[t]{3}{*}{0.000} \\
\hline & $2^{\text {nd }}$ application & 11.57 & \\
\hline & $3^{\text {rd }}$ application & 12.73 & \\
\hline \multirow{3}{*}{$\begin{array}{l}\text { The group receiving } \\
\text { treatments of }>12 \text {-month } \\
(n=25)\end{array}$} & $1^{\text {st }}$ application & 11.2 & \multirow[t]{3}{*}{0.002} \\
\hline & $2^{\text {nd }}$ application & 11.4 & \\
\hline & $3^{\text {rd }}$ application & 12.36 & \\
\hline
\end{tabular}

Table 2. Comparison of score of urticaria control test scores between each application

\begin{tabular}{|l|l|l|}
\hline & UCT Score & P-value \\
\hline \multirow{4}{*}{$\begin{array}{l}\text { The group receiving treatments of } \\
<12 \text {-month }(n=37)\end{array}$} & Application 1 vs 2 & 0.000 \\
\cline { 2 - 3 } & Application 1 vs 3 & 0.000 \\
\cline { 2 - 3 } & Application 2 vs 3 & 0.3 \\
\hline \multirow{3}{*}{$\begin{array}{l}\text { The group receiving treatments of } \\
>12 \text {-month ( } n=25)\end{array}$} & Application 1 vs 2 & 0.283 \\
\cline { 2 - 3 } & Application 1 vs 3 & 0.04 \\
\cline { 2 - 3 } & Application 2 vs 3 & 0.021 \\
\hline
\end{tabular}

successive application scores $(p<0.05)$ (Table 3). The second question of the UCT was "How much has your quality of life been affected by urticaria in the last 4 weeks?", and of the scores given for the first group the first application average was 2.05; the second 2.83; and the third 3.02. And there was a significant difference between the applications $(p<0.05)$. For the second group, the first application average was 2.32; the second 2.68; and the third 2.96; and there was a significant difference between the 3 successive application scores $(p<0.05)$. The third question of the UCT was "How successful was the urticaria treatment in terms of suppressing the disorders due to urticaria?". For the first group, the first, second, and third application averages of the scores given were $2.51 ; 3.13 ; 3.40$; and there was a significant difference between the 3 successive applications $(p<0.05)$. For the second group, the first, second, and third application averages

\begin{tabular}{|c|c|c|c|c|c|c|}
\hline & \multicolumn{3}{|c|}{$\begin{array}{l}\text { Treatments of } \\
<12 \text {-month }\end{array}$} & \multicolumn{3}{|c|}{ Treatments of $>12$-month } \\
\hline & & Mean & $\mathbf{p}$ & & Mean & p \\
\hline \multirow[t]{3}{*}{ Question1 } & $\begin{array}{l}1^{\text {st }} \\
\text { application }\end{array}$ & 2.16 & \multirow[t]{3}{*}{0.003} & $\begin{array}{l}1^{\text {st }} \\
\text { application }\end{array}$ & 2.16 & \multirow[t]{3}{*}{0.009} \\
\hline & $\begin{array}{l}2^{\text {nd }} \\
\text { application }\end{array}$ & 2.64 & & $\begin{array}{l}2^{\text {nd }} \\
\text { application }\end{array}$ & 2.44 & \\
\hline & $\begin{array}{l}3^{\text {rd }} \\
\text { application }\end{array}$ & 3.08 & & $\begin{array}{l}3^{\text {rd }} \\
\text { application }\end{array}$ & 2.84 & \\
\hline \multirow[t]{3}{*}{ Question2 } & $\begin{array}{l}1^{\text {st }} \\
\text { application }\end{array}$ & 2.05 & \multirow[t]{3}{*}{0} & $1^{\text {st }}$ application & 2.32 & \multirow[t]{3}{*}{0.005} \\
\hline & $\begin{array}{l}2^{\text {nd }} \\
\text { application }\end{array}$ & 2.83 & & $\begin{array}{l}2^{\text {nd }} \\
\text { application }\end{array}$ & 2.68 & \\
\hline & $\begin{array}{l}3^{\text {rd }} \\
\text { application }\end{array}$ & 3.02 & & $\begin{array}{l}3^{\text {rd }} \\
\text { application }\end{array}$ & 2.96 & \\
\hline \multirow[t]{3}{*}{ Question3 } & $\begin{array}{l}1^{\text {st }} \\
\text { application }\end{array}$ & 2.51 & \multirow[t]{3}{*}{0} & $\begin{array}{l}1^{\text {st }} \\
\text { application }\end{array}$ & 3.12 & \multirow[t]{3}{*}{0.039} \\
\hline & $\begin{array}{l}2^{\text {nd }} \\
\text { application }\end{array}$ & 3.13 & & $\begin{array}{l}2^{\text {nd }} \\
\text { application }\end{array}$ & 3.28 & \\
\hline & $\begin{array}{l}3^{\text {rd }} \\
\text { application }\end{array}$ & 3.4 & & $\begin{array}{l}3^{\text {rd }} \\
\text { application }\end{array}$ & 3.56 & \\
\hline \multirow[t]{3}{*}{ Question4 } & $\begin{array}{l}1^{\text {st }} \\
\text { application }\end{array}$ & 2.43 & \multirow[t]{3}{*}{0} & $\begin{array}{l}1^{\text {st }} \\
\text { application }\end{array}$ & 2.88 & \multirow[t]{3}{*}{0.368} \\
\hline & $\begin{array}{l}2^{\text {nd }} \\
\text { application }\end{array}$ & 2.94 & & $\begin{array}{l}2^{\text {nd }} \\
\text { application }\end{array}$ & 3 & \\
\hline & $\begin{array}{l}3^{\text {rd }} \\
\text { application }\end{array}$ & 3.21 & & $\begin{array}{l}3^{\text {rd }} \\
\text { application }\end{array}$ & 3.04 & \\
\hline
\end{tabular}

of the scores given were $3.12 ; 3.28 ; 3.56$; and there was a significant difference between the 3 successive applications $(p<0.05)$. Finally, for the last question of the UCT test, "How well was your urticaria suppressed in the last 4 weeks?", of the scores given for the first group, the first application average was 2,43; the second 2,94; and the third 3,21 . And there was a significant difference between the 3 successive applications $(p<0.05)$. For the second group, the first, second, and third 
application average were 2.88; 3.00; and 3.04; and there was not a significant difference between the 3 successive applications $(p>0.05)$.

\section{Discussion}

Urticaria is a skin disease accompanied by a severe pruritus demonstrating a fast progressive form, and is characterized by plaques developing in less than 24 hours, greatly impacting the quality of life with a tendency to become a chronic illness. Chronic urticaria is the form that lasts longer than a 6-week period, and although it has been demonstrated that it may relate to some other chronic infections, Helicobacter pylori infection, rheumatological diseases, and parasitic infections, no underlying cause has been identified for the majority of patients.

This study aims to evaluate the effectiveness of the omalizumab treatment on patients diagnosed with chronic urticaria with the 4-question UCT. For both of the two groups of patients receiving treatments lasting shorter and longer than 12-month periods there were significant differences between the 3 successive application scores and between the scores resulting from the analysis conducted for each of the questions. However, the improvement in the UCT results of the patient group receiving a shorter treatment was more pronounced as compared to the group receiving a longer treatment.

In their double-blind, placebo-controlled test Maurer et al. ${ }^{3}$ demonstrated that for the patients diagnosed with thyroid peroxidase $\lg E(+)$ chronic urticaria resistant to the antihistamine treatments, the omalizumab treatment caused a significant reduction in the urticaria activity score (UAS) which the patients had subjectively scored on a weekly basis during the course of 24 weeks as compared to the placebo group. In another Phase II prospective double-controlled blind test the patients with UAS values higher than 12 were separated into 4 groups; those who were administered 75 mg, 300 mg, and 600 mg omalizumab and the placebo group. They were all given a single dosage of subcutaneous injection and 4 weeks later their UAS values were measured again. It was noted that there was a significant reduction in the UAS values of those patients receiving the $300 \mathrm{mg}$ and $600 \mathrm{mg}$ omalizumab treatments as compared to the placebo group while there was no visible difference between the $75 \mathrm{mg}$ omalizumab and placebo groups ${ }^{4}$.

In another multicenter, randomized, double-blind test study, the patients diagnosed with chronic urticaria resistant to the antihistamine treatments were categorized into 4 groups. Three groups were administered 75 mg, 150 mg, 300 mg omalizumab treatments over 3 successive 4-week periods each. One group received a placebo treatment. Following a 12-week treatment period the patients were examined for 16 weeks. The patients were requested to fill out the daily urticaria patient score scale two times a day in an electronic form. The scale included scores for the pruritus severity, the plaque dimension, the impact of the symptoms on sleep and daily chores, the need for antihistamines, the presence of angioedema, and the need for medical assistance. The patients were also asked to fill out the Dermatology Quality of Life Index and Chronic Urticaria Quality of Life Questionnaire at the beginning, 12 , and $28^{\text {th }}$ weeks of treatments. At the end of the study a significant improvement was observed in the symptoms of the patient groups receiving the $150 \mathrm{mg}$ and $300 \mathrm{mg}$ omalizumab treatments on the $12^{\text {th }}$ week .
Zhao et al. $^{6}$ conducted a meta analysis based on 7 randomized and double-blind controlled test studies (XCUISITE, MYSTIQUE, ASTERIA I, ASTERIA II, GLACIAL, X-ACT, MOA) in which they evaluated the effect of the omalizumab treatment in patients diagnosed with chronic urticaria resistant to the antihistamine treatments. These studies were selected from the score-involving studies which assessed the weekly pruritus and plaque condition. For all studies the post-12-week treatment data were analyzed. At the end of the analysis a significant improvement in the scores of the group receiving the omalizumab treatment as compared to the placebo group was recorded. The improvement was the highest in the group receiving the $300 \mathrm{mg}$ treatment.

Lesiak et al. ${ }^{7}$ conducted a prospective study composed of 11 chronic urticaria patients taking omalizumab treatments. The patients were followed up during their routine clinical visits. At the end of the 24 weeks of treatment, both UAS and UCT results improved significantly. Miscellaneous scoring systems exist in the determination of urticaria disease activity, the most prevalent of which is the UAS. The UAS is a scoring system which is formed taking into consideration the pruritus severity and plaque number. The patient is asked to fill out this scoring system daily, and then the severity of the disease is evaluated based on 7-day data. Although UAS is a golden standard in the determination of disease severity, it carries some constraints. One, for example, is the possibility that the patient may not fully comply with the requirements of filling out the test and may miss some daily data. In addition, the UAS cannot be used by the technician in the determination of the disease activity during the first-encounter with the patient. Also, the UAS does not comprise data relating to angioedema, an important component of chronic urticaria. For this reason, the test may become deficient in the determination of the disease activity for chronic urticaria patients who develop findings only in the form of angioedema. Essentially it is a measure used in the determination of the disease severity and yields direct information regarding the control of the disease. Taking these shortcomings into account, Weller and his co-workers developed the $\mathrm{UCT}^{8}$. The UCT, comprising 4 questions, is a fast and practical evaluation test which can be applied to the patient by the technician. Another advantage of the UCT is that it allows the assessment of the results of the applied treatment. Considering all these features, we decided to use the UCT in our study.

\section{Study Limitation}

The primary limitation of our study was not being able to follow our patients monthly during their whole treatment period. Therefore, UCT results of three sequential injections were analyzed.

\section{Conclusion}

This study involves the analysis of the effectiveness of the omalizumab treatment on patients diagnosed with chronic urticaria by means of the UCT. The UCT results demonstrated a significant recovery in the patient groups who received the omalizumab treatment for both shorter than and longer than 12-month periods.

\section{Ethics}

Ethics Committee Approval: It wasn't obtained.

Informed Consent: It wasn't obtained.

Peer-review: Externally and internally peer-reviewed. 


\section{Authorship Contributions}

Surgical and Medical Practices: B.E., S.N.Y., Ö.A., Z.K., S.S., Concept: B.E., S.N.Y., Ö.A., Z.K., S.S., Design: B.E., S.N.Y., Ö.A., Z.K., S.S., Data Collection or Processing: B.E., S.N.Y., Ö.A., Z.K., S.S., Analysis or Interpretation: B.E., S.N.Y., Ö.A., Z.K., S.S., Literature Search: B.E., S.N.Y., Ö.A., Z.K., S.S., Writing: B.E., S.N.Y., Ö.A., Z.K., S.S.

Conflict of Interest: No conflict of interest was declared by the authors.

Financial Disclosure: The authors declared that this study received no financial support.

\section{References}

1. Zuberbier $T$, Aberer $W$, Asero $R$, et al: The EAACI/GA (2) LEN/EDF/WAO guideline for the definition, classification, diagnosis, and management of urticaria: the 2013 revision and update. Allergy 2014;69:868-87.

2. Göncü $\mathrm{E}, \mathrm{Aktan}$ Ş, Atakan N, et al: The turkish guideline for the diagnosis and management of urticaria-2016. Turkderm - Arch Turk Dermatol Venerology 2016;50:82-98.
3. Maurer M, Altrichter S, Bieber T, et al: Efficacy and safety of omalizumab in patients with chronic urticaria who exhibit IgE against thyroperoxidase. J Allergy Clin Immunol 2011;128:202-9.

4. Saini S, Rosen KE, Hsieh HJ, et al: A randomized, placebo-controlled, doseranging study of single-dose omalizumab in patients with $\mathrm{H} 1$-antihistaminerefractory chronic idiopathic urticaria. J Allergy Clin Immunol 2011;128:56773.

5. Maurer M, Rosen $\mathrm{K}, \mathrm{Hsieh} \mathrm{HJ}$, et al: Omalizumab for the treatment of chronic idiopathic or spontaneous urticaria. N Engl J Med 2013;3:924-35.

6. Zhao ZT, Ji CM, Yu WJ, et al: Omalizumab for the treatment of chronic spontaneous urticaria: A meta-analysis of randomized clinical trials. J Allergy Clin Immunol 2016;137:1742-50.

7. Lesiak A, Bednarski IA, Maćkowska A, et al: Omalizumab for urticaria treatment in clinical practice: a case series. Postepy Dermatol Alergol 2018;35:372-4.

8. Weller K, Groffik A, Church MK, et al: Development and validation of the urticaria control test: A patient-reported outcome instrument for assessing urticaria control. J Allergy Clin Immunol 2014;133:1365-72. 